\title{
Removal of chlorite from drinking water: laboratory and pilot-scale studies to predict activated carbon performance at full scale
}

\author{
Sabrina Sorlini ${ }^{a, *}$, Michela Biasibetti ${ }^{\mathrm{a}, \mathrm{b}}$, Francesca Gialdini ${ }^{\mathrm{a}}$, Maria Cristina Collivignarelli ${ }^{\mathrm{b}}$ \\ "University of Brescia, Department of Civil Engineering, Architecture, Land, Environment and of Mathematics, via Branze 43, \\ 25123 Brescia, Italy, Tel.+39 0303711299; Fax: +39 0303711312; email: sabrina.sorlini@unibs.it (S. Sorlini), Tel.+39 0303711302; \\ emails: michela.biasibetti@unibs.it (M. Biasibetti),francesca.gialdini@gmail.com (F. Gialdini) \\ ${ }^{b}$ University of Pavia, Department of Civil Engineering and Architecture, Via Ferrata, 1, 27100 Pavia, Italy, Tel. +39 0382985314; \\ Fax: +39 0382528422; email: michela.biasibetti01@universitadipavia.it (M. Biasibetti), Tel. +39 0382985312; Fax: +39 0382985589; \\ email: moristina.collivignarelli@unipv.it (M.C. Collivignarelli)
}

Received 27 July 2016; Accepted 29 September 2016

\section{A B S T R A C T}

\begin{abstract}
Chlorite is a by-product that can be produced in the disinfection process of a drinking water treatment plant (DWTP) using chlorine dioxide. The aim of this work was to evaluate the influence of the adsorption process with activated carbon on chlorite removal and to demonstrate how laboratory-scale and pilot-scale tests can be useful to predict granular activated carbon (GAC) performance on chlorite removal at full scale in a DWTP. A first series of tests were carried out at laboratory scale using small carbon columns. A second series of tests were performed at semi-full scale using a pilot plant at the DWTP of Vescovana (Padova, Italy). The laboratory-scale tests show that carbon pre-loading significantly reduces the $\mathrm{ClO}_{2}^{-}$removal yield, by about $30 \%-40 \%$. Both laboratory-scale tests and small column tests show that in virgin conditions the mineral carbon shows a higher $\mathrm{ClO}_{2}{ }^{-}$removal efficiency than the vegetal one, while in pre-loaded conditions an opposite behavior is observed. The results of the pilot plant test show that GAC ensures a good $\mathrm{ClO}_{2}^{-}$removal yield, close to $55 \%$. The results show that small column tests at laboratory scale are extremely useful to predict pilot column performance and, therefore, full-scale DWTP performance.
\end{abstract}

Keywords: Activated carbon; Chlorite; Drinking water treatment plant; Laboratory scale; Pilot plant

\section{Introduction}

Water disinfection is usually the last process in a drinking water treatment plant (DWTP) to prevent microbial contamination in the distribution network. However, this process requires the use of chemical disinfectants that can produce unwanted disinfection by-products (DBPs) with potential health concerns. In particular, if chlorine is used in final disinfection it can react with natural organic matter (NOM) to produce halogenated DBPs, especially trihalomethanes (THMs) and haloacetic acids (HAAs) [1]. Since total THMs increase with the chlorine dose, it is

* Corresponding author. important to evaluate the use of alternative disinfectants [2]. Chloramines can form THMs, trihalogenated HAAs, dihalogenated HAAs, $N$-nitrosodimethylamine, and total organic halogen (TOX), although generally lower than that from chlorination [3-5]. Concerning ozone, one of its main DBPs is bromate that increases with ozone dose and bromide concentration; ozone is not usually used in final disinfection because it does not provide a residual protection in the distribution network [2]. Concerning ultraviolet (UV) disinfection, it can produce concentrations of nitrite directly dependent on the UV dose applied and the nitrate concentration in water and aldehydes can be formed as a result of the UV irradiation of solutions of humic acid [6]. Moreover, UV disinfection does not provide residual protection in the water distribution system [7]. 
For these reasons, there is an increasing interest about the use of chlorine dioxide $\left(\mathrm{ClO}_{2}\right)$ as alternative disinfectant in DWTPs. Disinfection with $\mathrm{ClO}_{2}$ is commonly applied in DWTPs as it is more effective than chlorine or chloramines as disinfectant against micro-organisms, it controls taste and odor better than chlorine in some cases, and it forms less THMs, HAAs, and TOX than free chlorine $[7,8]$. Moreover, it ensures a residual concentration of free chlorine at the point of delivery at or above $0.2 \mathrm{mg} \mathrm{L}^{-1}$ [9-13]. However, $\mathrm{ClO}_{2}$ can react with NOM to produce unwanted DBPs, such as chlorite $\left(\mathrm{ClO}_{2}^{-}\right)$and chlorate $\left(\mathrm{ClO}_{3}^{-}\right)$[13]. Since the exposure to these compounds can determine oxidative damage to red blood human cells, the World Health Organization fixed a regulation limit of $5 \mathrm{mg} \mathrm{L}^{-1}$ for chlorine dosage in disinfection and $700 \mu \mathrm{g} \mathrm{L} \mathrm{L}^{-1}$ for both $\mathrm{ClO}_{2}^{-}$and $\mathrm{ClO}_{3}^{-}$in drinking water [13-16]. In order to minimize $\mathrm{ClO}_{2}^{-}$and $\mathrm{ClO}_{3}^{-}$formation in final disinfection, $\mathrm{ClO}_{2}$ demand in final disinfection can be reduced [17]. Different treatment processes can be employed for $\mathrm{ClO}_{2}{ }^{-}$removal, such as reduction with ferrous ions, adsorption with activated carbon, oxidation with ozone, and reduction with sulfur compounds [18-21]. In particular, granular activated carbon (GAC) can remove $\mathrm{ClO}_{2}^{-}$because of adsorption and chemical reduction $[20,21]$. Under typical drinking water conditions $(<1-2 \mathrm{mg}$ $\mathrm{L}^{-1} \mathrm{ClO}_{2}^{-}$) a removal of $130 \mathrm{mg} \mathrm{ClO}{ }_{2}^{-}$per gram of $\mathrm{GAC}$ can be obtained with a GAC lifetime of about 8-12 months, an empty bed contact time (EBCT) of 10-15 min and a maximum $\mathrm{ClO}_{2}{ }^{-}$concentration in the effluent of $0.2 \mathrm{mg} \mathrm{L}^{-1}$ [22]. Moreover, the GAC performance in terms of $\mathrm{ClO}_{2}^{-}$removal significantly varies if a virgin or a thermally regenerated GAC is used instead of an exhausted GAC. Some researchers found that thermally regenerated GAC demonstrates good removal for both organic matter $(70 \%-80 \%)$ and $\mathrm{ClO}_{2}^{-}$ $(100 \%)$. With exhausted GAC, organic matter removal can be reduced from $40 \%-50 \%$ (without $\mathrm{ClO}_{2}^{-}$) to $5 \%-7 \%$ (when water is spiked with $\mathrm{ClO}_{2}^{-}$) while $\mathrm{ClO}_{2}^{-}$removal remains significant, with yield of about 50\% [20]. Other important factors that influence the $\mathrm{ClO}_{2}^{-}$removal are the effect of GAC pre-loading and the EBCT [23]. Some authors observed that GAC pre-loaded with $\mathrm{NOM}$ has a low $\mathrm{ClO}_{2}{ }^{-}$removal efficiency $(15 \%-20 \%)$ and an increase in EBCT from 2 to $10 \mathrm{~min}$ increases the removal efficiency from $30 \%$ to $80 \%$ [21].

Several tests are available at the laboratory scale or at the pilot scale in order to predict the GAC performance at the full scale in terms of $\mathrm{ClO}_{2}^{-}$removal. A test aimed at comparing the adsorption capacity of different activated carbons is the Freundlich isotherm determination at the laboratory scale in batch conditions. Some researchers determined the Freundlich isotherms related to the $\mathrm{ClO}_{2}^{-}$removal and found that mineral meso-porous activated carbons allow a higher $\mathrm{ClO}_{2}^{-}$removal than the vegetal micro-porous GACs; in particular, using the mineral carbons, a maximum $\mathrm{ClO}_{2}^{-}$removal of $99 \%$ was obtained with demineralized water, $80 \%$ with groundwater, and $70 \%$ with surface water [19]. Moreover, rapid small-scale column tests (RSSCTs), pilot-scale tests, and mathematical models can be studied to predict GAC performance at the full scale. Pilot studies can predict full-scale GAC performance very accurately; however, they require very long time to obtain results, they are expensive and must be conducted onsite [24]. Some authors tested pilot columns containing virgin and pre-loaded GACs; they reported a $\mathrm{ClO}_{2}^{-}$removal of $93 \%-96 \%$ using the virgin GACs and of $13 \%-21 \%$ using the pre-loaded GAC [21]. RSSCTs can also predict the GAC full-scale performance accurately, without isotherm studies; moreover, they require a small volume of water and they can be conducted in a fraction of time required to conduct pilot studies. Consequently, replacing a pilot study with an RSSCT significantly reduces the time and cost of a full-scale design. However, the results of RSSCT are site specific and only valid for the raw water tested [24]. No specific data are available in the literature concerning the use of RSSCT to evaluate the $\mathrm{ClO}_{2}^{-}$removal. However, some authors compared RSSCTs to pilot columns for the removal of background dissolved organic carbon in five surface waters and one groundwater and reported that the RSSCT data agrees well with the pilot column data [25]. Mathematical models, once calibrated, can be used to predict the impact of EBCT and changes in the influent concentration, but they cannot predict the total organic carbon breakthrough and must be used in conjunction with pilot or RSSCT data. However, they can predict the breakthrough of synthetic organic compounds with $20 \%-50 \%$ error, but only after a calibration with pilot or RSSCT data [24].

Predicting the GAC performance at the full scale with laboratory- and pilot-scale tests allows to evaluate the implementation of a GAC treatment in a DWTP or to optimize the performance of an existing GAC stage.

This study presents the results of laboratory- and pilot-scale column tests using GAC to reduce the $\mathrm{ClO}_{2}^{-}$ concentration in drinking water. Small and pilot GAC columns were tested, comparing a mineral and a vegetal $\mathrm{GAC}$, in order to evaluate the GAC performance on $\mathrm{ClO}_{2}^{-}$ removal in virgin and pre-loaded conditions. Therefore, this study has the objective to evaluate how these tests can be useful to predict the GAC full-scale performance in a DWTP. The results may be of interest for many water utilities that employ activated carbon in the DWTP treatment chain or are interested in upgrading the DWTP adding a GAC adsorption stage.

\section{Methods}

\subsection{DWTP of Vescovana (Padova, Italy)}

The DWTP of Vescovana (Padova, Italy) treats an average water flow of $24 \mathrm{ML} \mathrm{d}^{-1}$. The plant treats surface water, from Adige river, with the following parameters to be lowered/removed: turbidity, iron, aluminum, total coliform, and Escherichia Coli.

The plant is composed of the following processes: pre-oxidation with $\mathrm{ClO}_{2}$ and, occasionally, with sodium hypochlorite $(\mathrm{NaClO})$; coagulation in tank with ferric chloride $\left(\mathrm{FeCl}_{3}\right)$, flocculation and sedimentation; granular filtration in mixed GAC-sand filters; GAC adsorption; and final disinfection with $\mathrm{ClO}_{2}$.

\subsection{Experimental design and methods}

In order to evaluate $\mathrm{ClO}_{2}^{-}$removal with $\mathrm{GAC}$, two types of experimental test were performed (Fig. 1): 

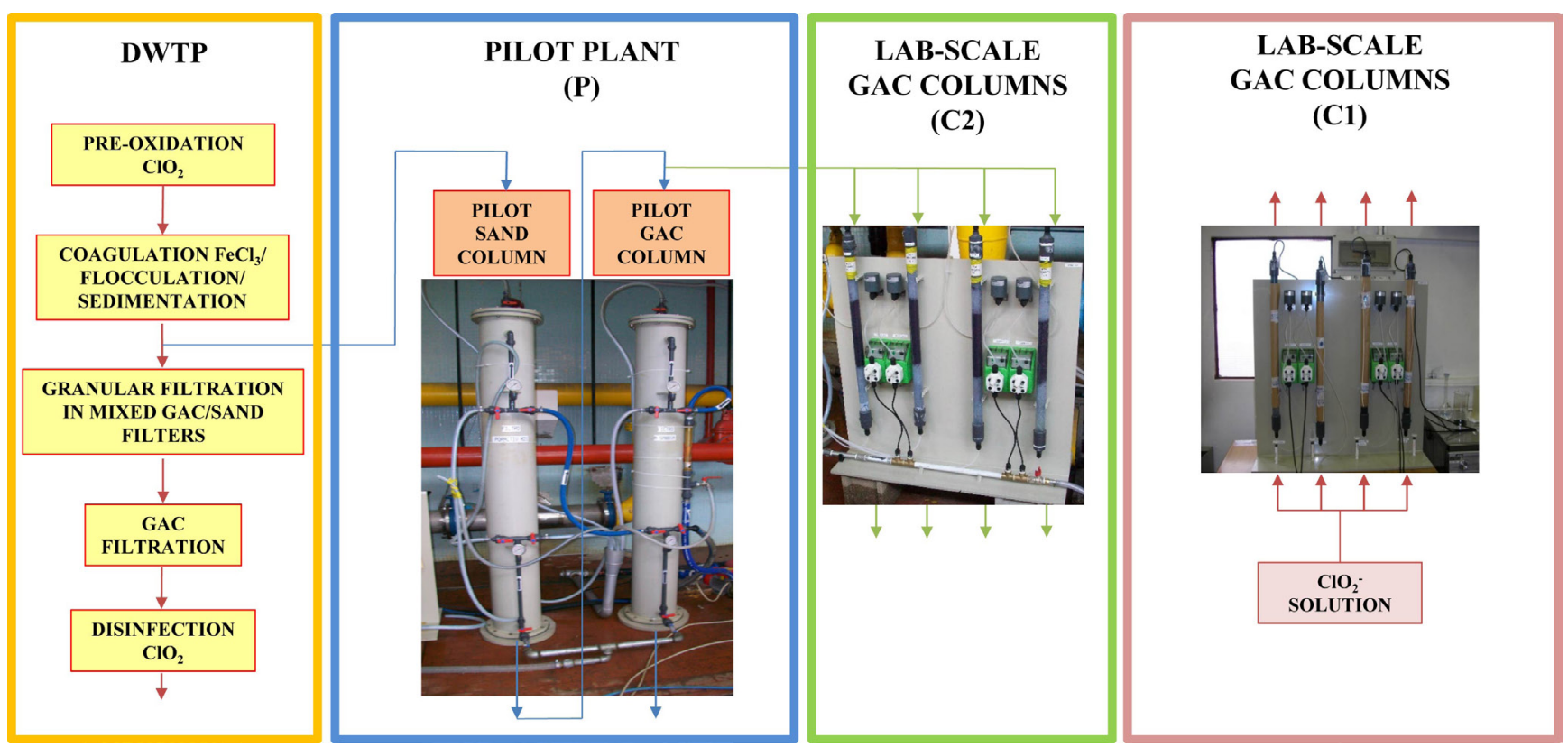

Fig. 1. Flow chart of the experimental tests.

- Adsorption with activated carbon with small continuous flow column tests at laboratory scale (C).

- Adsorption with activated carbon with continuous flow pilot plant at the DWTP at semi-full scale (P).

These tests were conducted by applying the operating conditions reported in Table 1.

Two activated carbons with different physicochemical characteristics were tested: a mineral GAC (Poractiv M21, Hydro-line) and a vegetal GAC (Poractiv C24, Hydro-line) (Table 2). In some cases (Table 1), carbons were also tested in pre-loaded conditions, in order to simulate the saturation of the various GAC pore fractions, thus to investigate GAC performance on chlorite removal in exhausted conditions. The GAC pre-loading was carried out by treating the virgin carbon $(50 \mathrm{~g})$ with a solution containing demineralized water $(800 \mathrm{~mL})$, methylene blue (13 and $14.5 \mathrm{~g}$, respectively, for M21 and C24), iodine (48.5 and $60 \mathrm{~g}$, respectively, for M21 and C24), and phenol (36 and $25 \mathrm{~g}$, respectively, for M21 and C24). The chemicals employed for this goal were chosen on the basis of their molecular diameter. Indeed, methylene blue (molecular diameter of $1.5 \mathrm{~nm}$ ) was used to pre-load GAC meso-pores, iodine (molecular diameter of $1.0 \mathrm{~nm}$ ) and phenol (molecular diameter of $0.7-0.8 \mathrm{~nm}$ ) were used to saturate GAC micro-pores. The pore dimensions were considered according to the International Union of Pure and Applied Chemistry. The virgin GAC was continuously mixed with this solution for 20 days to simultaneously homogenize all the compounds with carbon. The pre-loading achievement was evaluated by analyzing the methylene blue adsorption, the iodine number, and the phenol number for each carbon. In section 3, the pre-loading achievement is not shown, since it was not the objective of this study. After the saturation period, pre-loaded carbons were washed with distilled water to avoid release of excess compounds not adsorbed by GAC that could interfere during the subsequent water analysis.

Then, the pre-loaded carbons were used in the column tests (Table 1).

\subsection{Column tests at laboratory scale (C)}

Two different column tests were carried out at laboratory scale in order to evaluate the GAC adsorption capacity in terms of $\mathrm{ClO}_{2}^{-}$removal.

In the first column test (C1), four small columns (diameter $=3 \mathrm{~cm}$ and height $=62 \mathrm{~cm}$ ), respectively, containing the mineral and the vegetal carbon (30-40 g), each in virgin and pre-loaded conditions, were tested. The columns, installed in parallel onto vertical panels, were connected to peristaltic pumps, which allowed a continuous upflow at a constant rate. Each column operated with a 5 min EBCT, a $1 \mathrm{~L} \mathrm{~h}^{-1}$ flow, and a $1.4 \mathrm{~m} \mathrm{~h}^{-1}$ hydraulic load (Table 1). The columns were fed with a $\mathrm{ClO}_{2}^{-}$solution, prepared by adding $\mathrm{NaClO}_{2}$ solution (31\%) to demineralized water, with an initial $\mathrm{ClO}_{2}^{-}$concentration of $1 \mathrm{mg} \mathrm{L}^{-1}$. The virgin carbon and the pre-loaded carbon columns worked for a period of about 180 and 80 days, respectively. During the operating period, the residual $\mathrm{ClO}_{2}^{-}$was analyzed on samples collected approximately once a day at the outlet of the columns.

In the second column test (C2), four small columns (diameter $=3 \mathrm{~cm}$ and height $=64 \mathrm{~cm}$ ) were tested in different operating conditions (Table 1). Two columns were filled with the mineral carbon, one with the vegetal carbon, and one with the mineral pre-loaded carbon (80 g). The columns, installed in parallel onto vertical panels, were connected to peristaltic pumps, which allowed a continuous downflow at a constant rate. Water coming from the outlet of the sand column of the pilot plant $(\mathrm{P})$ was used to feed the columns. During the operating period, $\mathrm{ClO}_{2}^{-}$was analyzed on samples collected once a week at the outlet of the columns.

All the columns, both during $\mathrm{C} 1$ and $\mathrm{C} 2$ test, were never backwashed. 
Table 1

Operating conditions of the experimental tests

\begin{tabular}{|c|c|c|c|c|c|}
\hline Test & & Feed & GAC & Operating conditions & $\begin{array}{l}\text { Column dimensions and } \\
\text { stratigraphy }\end{array}$ \\
\hline \multirow[t]{3}{*}{$\begin{array}{l}\text { Column } \\
\text { tests }(\mathrm{C})\end{array}$} & $\mathrm{C} 1$ & $\mathrm{ClO}_{2}^{-}$solution & $\begin{array}{l}\min , \text { veg, } \\
\min _{\mathrm{P}^{\prime}} \text { veg }_{\mathrm{P}}\end{array}$ & $Q=1 \mathrm{~L} \mathrm{~h}^{-1}, \mathrm{EBCT}=5 \mathrm{~min}$ & $\begin{array}{l}\text { - Dimensions: } d=3 \mathrm{~cm}, h=62 \mathrm{~cm} \\
\text { - Stratigraphy (bottom upward): } \\
1 \mathrm{~cm} \text { cotton } \\
12 \mathrm{~cm} \text { glass spheres } d=6 \mathrm{~mm} \\
12 \mathrm{~cm} \text { glass spheres } d=3 \mathrm{~mm} \\
12 \mathrm{~cm} \text { GAC } \\
12 \mathrm{~cm} \text { glass spheres } d=3 \mathrm{~mm} \\
12 \mathrm{~cm} \text { glass spheres } d=6 \mathrm{~mm}\end{array}$ \\
\hline & $\mathrm{C} 2$ & $\begin{array}{l}\text { Water out pilot } \\
\text { sand column }\end{array}$ & $\min$ & $\begin{array}{l}\text { - } Q=1 \mathrm{~L} \mathrm{~h}^{-1}, \mathrm{EBCT}=10 \mathrm{~min} \\
\text { - } Q=0.5 \mathrm{~L} \mathrm{~h}^{-1}, \mathrm{EBCT}=20 \mathrm{~min}\end{array}$ & $\begin{array}{l}\text { - Dimensions: } d=3 \mathrm{~cm}, h=64 \mathrm{~cm} \\
\text { - Stratigraphy (bottom upward): } \\
1 \mathrm{~cm} \text { cotton } \\
10 \mathrm{~cm} \text { glass spheres } d=6 \mathrm{~mm} \\
10 \mathrm{~cm} \text { glass spheres } d=3 \mathrm{~mm}\end{array}$ \\
\hline & & & veg & $Q=1 \mathrm{~L} \mathrm{~h}^{-1}, \mathrm{EBCT}=10 \mathrm{~min}$ & $\begin{array}{l}24 \mathrm{~cm} \text { GAC } \\
10 \mathrm{~cm} \text { glass spheres } d=3 \mathrm{~mm}\end{array}$ \\
\hline \multirow[t]{2}{*}{$\begin{array}{l}\text { Pilot } \\
\text { plant }(\mathrm{P})\end{array}$} & $\begin{array}{l}\text { Sand } \\
\text { column }\end{array}$ & $\begin{array}{l}\text { Water out coag/ } \\
\text { flocc/sed at the } \\
\text { DWTP }\end{array}$ & $\begin{array}{l}\min _{\mathrm{P}} \\
-\end{array}$ & $\begin{array}{l}Q=1 \mathrm{~L} \mathrm{~h}^{-1}, \mathrm{EBCT}=10 \mathrm{~min} \\
Q=500 \mathrm{~L} \mathrm{~h}^{-1}, \mathrm{EBCT}=5 \mathrm{~min}\end{array}$ & $\begin{array}{l}10 \mathrm{~cm} \text { glass spheres } d=6 \mathrm{~mm} \\
\text { - Dimensions: } d=25 \mathrm{~cm}, h=2 \mathrm{~m} \\
\text { - Stratigraphy (bottom upward): } \\
20 \mathrm{~cm} \text { gravel } d=3-5 \mathrm{~mm} \\
70 \mathrm{~cm} \text { sand } d=0.6-2.8 \mathrm{~mm} \\
30 \mathrm{~cm} \text { anthracite }\end{array}$ \\
\hline & $\begin{array}{l}\text { GAC } \\
\text { column }\end{array}$ & $\begin{array}{l}\text { Water out pilot } \\
\text { sand column }\end{array}$ & $\min$ & $Q=500 \mathrm{~L} \mathrm{~h}^{-1}, \mathrm{EBCT}=5 \mathrm{~min}$ & $\begin{array}{l}\text { - Dimensions: } d=25 \mathrm{~cm}, h=2 \mathrm{~m} \\
\text { - Stratigraphy (bottom upward): } \\
20 \mathrm{~cm} \text { gravel } d=3-5 \mathrm{~mm} \\
100 \mathrm{~cm} \text { GAC }\end{array}$ \\
\hline
\end{tabular}

Note: $\min$ - mineral; veg - vegetal; $\min _{\mathrm{p}}$ - mineral pre-loaded; veg $_{\mathrm{p}}$ - vegetal pre-loaded; coag/flocc/sed - coagulation/flocculation/ sedimentation; $d$-diameter; $h$ - height.

Table 2

Physicochemical characteristics of the activated carbons employed in the experimental tests

\begin{tabular}{|c|c|c|}
\hline Parameter & $\begin{array}{l}\text { Poractiv M21 } \\
\text { (Hydro-line) }\end{array}$ & $\begin{array}{l}\text { Poractiv C24 } \\
\text { (Hydro-line) } \\
\end{array}$ \\
\hline Origin & Mineral & Vegetal \\
\hline Porosity & $\begin{array}{l}\text { Macro- and } \\
\text { micro-porous }\end{array}$ & $\begin{array}{l}\text { Micro- } \\
\text { porous }\end{array}$ \\
\hline $\begin{array}{l}\text { Surface area Brunauer- } \\
\text { Emmett-Teller, } \mathrm{m}^{2} \mathrm{~g}^{-1}\end{array}$ & 1,038 & 1,207 \\
\hline Iodine number, $\mathrm{mg} \mathrm{g}^{-1}$ & 970 & 1,204 \\
\hline Uniformity coefficient & 1.61 & 1.64 \\
\hline Density, loose packed, $\mathrm{kg} \mathrm{m}^{-3}$ & 428 & 456 \\
\hline Density, dense packed, $\mathrm{kg} \mathrm{m}^{-3}$ & 463 & 491 \\
\hline Effective size, $\mathrm{mm}$ & 0.75 & 0.76 \\
\hline Micro-pores volume, $\mathrm{mm}^{3} \mathrm{~g}^{-1}$ & 197 & 461 \\
\hline Meso-pores volume, $\mathrm{mm}^{3} \mathrm{~g}^{-1}$ & 123 & 42 \\
\hline Macro-pores volume, $\mathrm{mm}^{3} \mathrm{~g}^{-1}$ & 233 & 58 \\
\hline
\end{tabular}

\subsection{Pilot plant at semi-full scale $(P)$}

After the column tests, a pilot plant at semi-full scale was tested in order to evaluate the carbon adsorption capacity in terms of $\mathrm{ClO}_{2}^{-}$removal in the DWTP. A pilot sand column (diameter $=25 \mathrm{~cm}$ and height $=2 \mathrm{~m}$ ) followed by a pilot GAC column (diameter $=25 \mathrm{~cm}$ and height $=$ $2 \mathrm{~m}$ ) was installed after the coagulation, flocculation, and sedimentation process of the DWTP. The GAC column was filled with the mineral carbon, since it resulted the best carbon in terms of adsorption capacity from previous column tests at laboratory scale (C1 and $\mathrm{C} 2$ ). Both columns, made in polypropylene with $1 / 2^{\prime \prime}$ polyvinyl chloride valves and $1 / 2^{\prime \prime}$ manual vent, operated with a $5 \mathrm{~min}$ EBCT at a $500 \mathrm{~L} \mathrm{~h}^{-1}$ flow (the flow was monitored by a flowmeter installed at the inlet of the pilot sand column) with a continuous downflow at a constant rate (Table 1). The backwash was made on both sand column and GAC column, by a single upflow backwash phase with water, for $1 \mathrm{~h}$ a day at a 3 bar pressure. The $\mathrm{ClO}_{2}^{-}$concentration was analyzed on samples collected once a week at the inlet and outlet of the pilot sand column, and at the outlet of the pilot GAC column. 


\subsection{Analytical methods}

The methylene blue adsorption, the iodine number, and the phenol adsorption were analyzed with a spectrophotometer (PerkinElmer Lambda 25) [26-28]. The $\mathrm{ClO}_{2}^{-}$concentration was analyzed with Ion Chromatograph 761 Compact IC Metrohm [29].

\section{Results and discussion}

\subsection{Column tests at laboratory scale (C)}

In the first column test $(\mathrm{C} 1)$, residual $\mathrm{ClO}_{2}^{-}$was determined on samples collected at the outlet of the four GAC columns, each operating with a 5 min EBCT (Fig. 2).

Comparing the virgin carbons, the results show that the mineral GAC guarantees the complete $\mathrm{ClO}_{2}^{-}$removal for about 3 months, while the vegetal GAC for about 1 month. Moreover, after 6 months the $\mathrm{ClO}_{2}^{-}$concentration at the outlet of the mineral GAC column is half the one at the outlet of the vegetal one. Therefore, in virgin conditions the mineral GAC is more efficient than the vegetal. Further, with both the mineral and the vegetal GAC after 6 months the $\mathrm{ClO}_{2}^{-}$concentration is significantly below the regulation limit of $700 \mu \mathrm{g} \mathrm{L}^{-1}$.

Comparing the pre-loaded carbons, during the first month the mineral GAC shows a higher efficiency than the vegetal one; however, after this period the vegetal GAC shows a higher efficiency, reaching a removal yield twice than the mineral GAC after 80 days of operation. Therefore, in pre-loaded conditions the vegetal GAC is more efficient than the mineral, as opposed to the results obtained in virgin conditions.

Comparing virgin and pre-loaded carbons, the $\mathrm{ClO}_{2}^{-}$ trends at the outlet of the vegetal GACs are similar, while a significant difference is observed between the mineral GACs. In fact, since the vegetal carbon is micro-porous, $\mathrm{ClO}_{2}^{-}$is less adsorbed both in virgin and pre-loaded conditions, with a negligible difference.

In the second column test (C2) (Fig. 3), the virgin mineral GAC operating with a 10 min EBCT guarantees a complete $\mathrm{ClO}_{2}^{-}$removal for about 5 months, and then $\mathrm{ClO}_{2}^{-}$is always below $200 \mu \mathrm{g} \mathrm{L}^{-1}$ till the end of the monitoring period. At the outlet of the virgin mineral GAC operating with a $20 \mathrm{~min}$ $\mathrm{EBCT}$, a complete $\mathrm{ClO}_{2}{ }^{-}$removal is registered during all the monitoring period. These results show that a lower EBCT implies the breakthrough achievement in a shorter period. This suggest that with a higher water flow, thus with a lower EBCT, the GAC operates with a higher $\mathrm{ClO}_{2}^{-}$load and, therefore, it rapidly achieves the breakthrough. Moreover, it is important to highlight that $\mathrm{ClO}_{2}^{-}$removal by GAC is the product of two steps: $\mathrm{ClO}_{2}^{-}$adsorption on GAC sites and its reduction to chloride, the primary final reaction product. Therefore, the $\mathrm{ClO}_{2}^{-}$removal observed with a low EBCT is mainly due to the reduction of $\mathrm{ClO}_{2}^{-}$to chloride, while the adsorption of $\mathrm{ClO}_{2}^{-}$on the GAC active sites is a slower process that increases only at a higher EBCT [20].

Unlike the results of the $\mathrm{C} 1$ column tests (Fig. 2), in the $\mathrm{C} 2$ column test at the same flow and EBCT $\left(Q=1 \mathrm{~L} \mathrm{~h}^{-1}, \mathrm{EBCT}=\right.$ $10 \mathrm{~min}$ ) in virgin conditions the vegetal GAC shows a greater $\mathrm{ClO}_{2}^{-}$removal efficiency than the mineral GAC; in fact, considering the vegetal GAC column, a complete $\mathrm{ClO}_{2}^{-}$removal is registered during all the monitoring period.

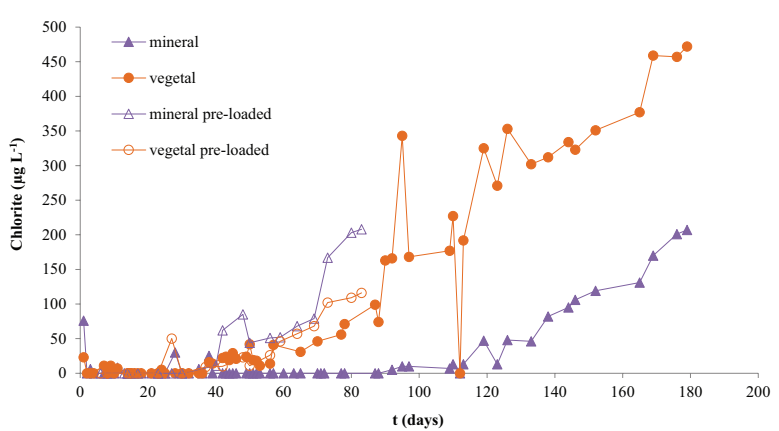

Fig. 2. Residual $\mathrm{ClO}_{2}{ }^{-}$concentration in samples collected at the outlet of the GAC columns operating with a $5 \mathrm{~min} \mathrm{EBCT}$, in the first column test (C1).

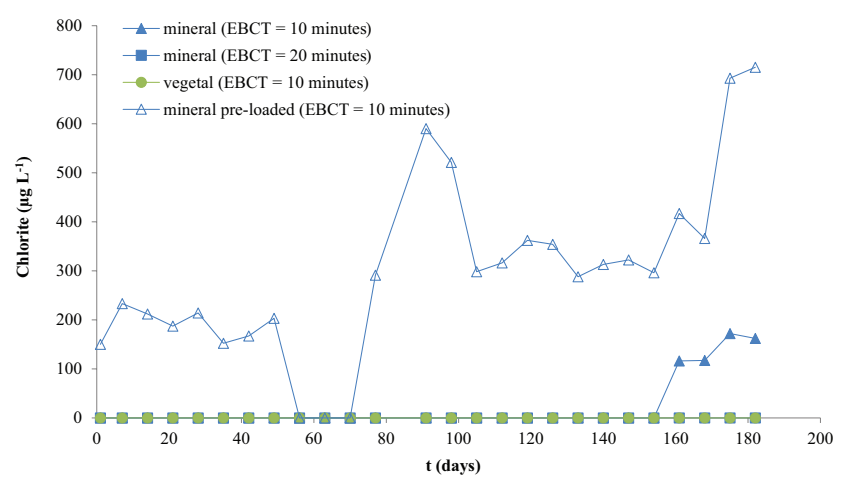

Fig. 3. Residual $\mathrm{ClO}_{2}{ }^{-}$concentration in samples collected at the outlet of the carbon columns operating with 10 and 20 min EBCT, in the second column test (C2).

The $\mathrm{ClO}_{2}^{-}$concentration at the outlet of the pre-loaded mineral GAC is detected from the first day of operation and ranges between 150 and $600 \mu \mathrm{g} \mathrm{L}^{-1}$; only after 6 months it exceeds the regulation limit of $700 \mu \mathrm{g} \mathrm{L}^{-1}$. The comparison between virgin and pre-loaded mineral GACs (both operating with $Q=1 \mathrm{~L} \mathrm{~h}^{-1}$ and contact time of $10 \mathrm{~min}$ ) agrees with the results of the $\mathrm{C} 1$ column test (Fig. 2), since the carbon pre-loading significantly reduces the $\mathrm{ClO}_{2}^{-}$removal yield. This result confirms that $\mathrm{ClO}_{2}^{-}$removal process loses its efficiency when GAC is pre-loaded with organic matter and specific ions [20].

\subsection{Pilot plant at semi-full scale $(P)$}

The residual $\mathrm{ClO}_{2}^{-}$concentrations were determined on samples collected at the inlet and outlet of the pilot sand column, and at the outlet of the pilot GAC column (Fig. 4).

The $\mathrm{ClO}_{2}^{-}$concentration at the inlet of the pilot sand column is not constant and it is proportional to the $\mathrm{ClO}_{2}$ dosage employed in the pre-oxidation process: when the dosage is high (0.8-0.9 $\left.\mathrm{mg} \mathrm{L}^{-1}\right)$, the $\mathrm{ClO}_{2}^{-}$concentration is high of course, but always below the regulation limit of $700 \mu \mathrm{g} \mathrm{L}^{-1}$. The average $\mathrm{ClO}_{2}^{-}$concentration at the inlet of the pilot sand column is $646 \mu \mathrm{g} \mathrm{L}^{-1}$ (maximum 1,042 $\mathrm{g} \mathrm{L} \mathrm{L}^{-1}$ and minimum $411 \mu \mathrm{g} \mathrm{L}^{-1}$ ).

Since the $\mathrm{ClO}_{2}^{-}$concentration trends at the inlet and outlet of the pilot sand column are similar, it can be stated that the pilot sand filter does not guarantee high $\mathrm{ClO}_{2}^{-}$removal 


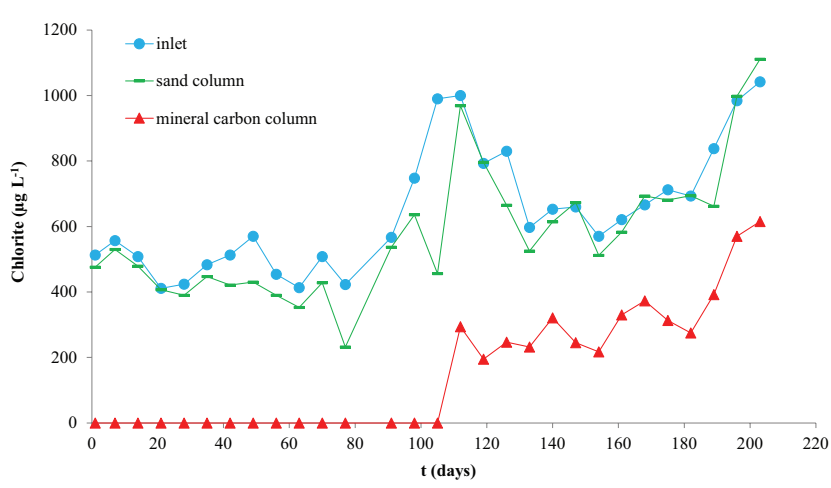

Fig. 4. Residual $\mathrm{ClO}_{2}^{-}$concentration in samples collected at the inlet and outlet of the sand column, and at the outlet of the mineral GAC column, both operating with a 5 min EBCT, in the pilot test $(\mathrm{P})$.

yields and even, sometimes, the concentration at the outlet is slightly higher than the one at the inlet. Its average $\mathrm{ClO}_{2}^{-}$ removal yield is about $11 \%$, the average $\mathrm{ClO}_{2}^{-}$concentration at the outlet of the pilot sand column is $579 \mu \mathrm{g} \mathrm{L}^{-1}$ and it varies in the range of $232-1,110 \mu \mathrm{g} \mathrm{L}^{-1}$.

The pilot GAC column guarantees a complete $\mathrm{ClO}_{2}^{-}$ removal for 3.5 months and, then, $\mathrm{ClO}_{2}^{-}$concentration increases varying between 200 and $400 \mu \mathrm{g} \mathrm{L} \mathrm{L}^{-1}$. After 190 days the carbon exhaustion process further increases, since the $\mathrm{ClO}_{2}^{-}$concentration at the inlet of the pilot sand column increases up to $800 \mu \mathrm{g} \mathrm{L}^{-1}$; however, after 200 days the $\mathrm{ClO}_{2}^{-}$ concentration at the outlet of the GAC column is still below the regulation limit of $700 \mu \mathrm{g} \mathrm{L}^{-1}$. From 3.5 months until the end of the monitoring period the average $\mathrm{ClO}_{2}^{-}$removal yield from the outlet of the pilot sand column to the outlet of the pilot GAC column is close to $55 \%$.

In the first 3.5 months, the $\mathrm{ClO}_{2}^{-}$removal is mainly due to the reduction of $\mathrm{ClO}_{2}^{-}$to chloride, while after this period the $\mathrm{ClO}_{2}^{-}$is removed by the adsorption process on the GAC active sites, which is a slow process that can be observed in the long period [20].

\subsection{Comparison between column tests at laboratory scale and pilot column test at semi-full scale}

The $\mathrm{ClO}_{2}^{-}$concentration at the outlet of the virgin vegetal GAC column at laboratory scale after 5 and $10 \mathrm{~min}$ EBCT throughout the column operating period is shown in Fig. 5.

It can be stated that the vegetal GAC column with a $10 \mathrm{~min}$ EBCT (C2) ensure a complete $\mathrm{ClO}_{2}^{-}$removal during all the monitoring period, while with a $5 \mathrm{~min}$ EBCT (C1) the complete removal is registered only during the first month of operation. Then, only with a 5 min EBCT a gradual increase is observed by reaching concentrations up to $470 \mu \mathrm{g} \mathrm{L}^{-1}$. Therefore, as expected, a lower EBCT implies an acceleration in the carbon breakthrough achievement. This result again agrees with the fact that with a higher water flow, the GAC is more charged by $\mathrm{ClO}_{2}^{-}$and, therefore, it rapidly achieves the breakthrough. Moreover, at a low EBCT the predominant $\mathrm{ClO}_{2}^{-}$removal process is the reduction of $\mathrm{ClO}_{2}^{-}$to chloride, while the adsorption of $\mathrm{ClO}_{2}{ }^{-}$on the GAC active sites increases at a higher EBCT [20].

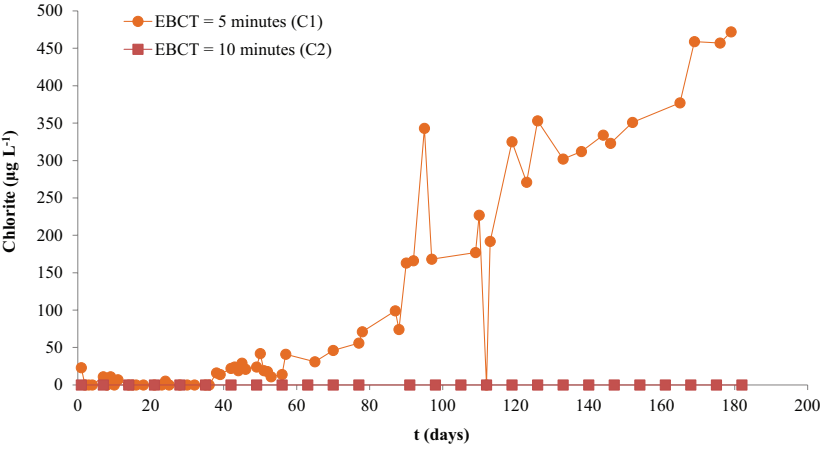

Fig. 5. Residual $\mathrm{ClO}_{2}^{-}$concentration in samples collected at the outlet of the virgin vegetal GAC columns operating with 5 and 10 min EBCT, respectively, in the first and second column tests (C1 and $\mathrm{C} 2)$.

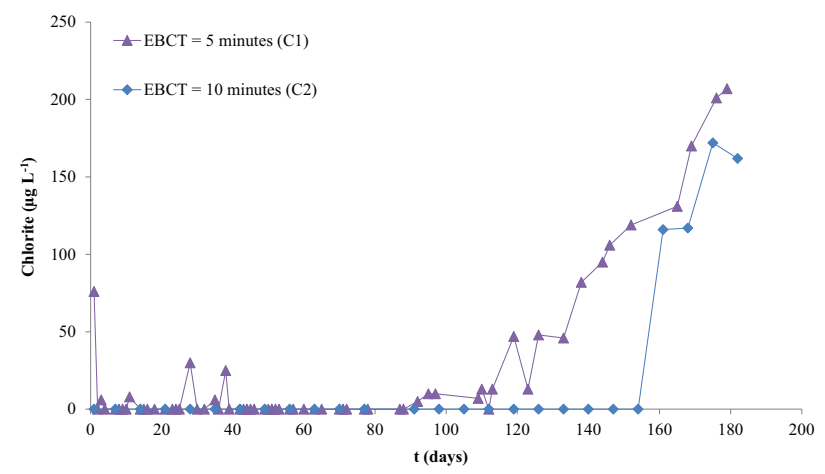

Fig. 6. Residual $\mathrm{ClO}_{2}{ }^{-}$concentration in samples collected at the outlet of the virgin mineral GAC columns operating with 5 and 10 min EBCT, respectively, in the first and second column tests (C1 and $\mathrm{C} 2$ ).

The $\mathrm{ClO}_{2}{ }^{-}$concentration at the outlet of the virgin mineral GAC column after 5 and $10 \mathrm{~min}$ EBCT throughout the column operating period is shown in Fig. 6.

In virgin conditions, the mineral GAC operating with a 10 min EBCT guarantees a complete $\mathrm{ClO}_{2}^{-}$removal for a longer period than with a 5 min EBCT. Then, a sharp increase up to $170 \mu \mathrm{g} \mathrm{L}^{-1}$ is observed with a $10 \mathrm{~min}$ EBCT, while a gradual increase up to $200 \mu \mathrm{g} \mathrm{L}^{-1}$ is shown with a $5 \mathrm{~min}$ EBCT.

The $\mathrm{ClO}_{2}^{-}$concentration at the outlet of the pre-loaded mineral GAC column after 5 and 10 min EBCT throughout the column operating period is shown in Fig. 7.

In pre-loaded conditions, the mineral GAC shows an anomalous higher $\mathrm{ClO}_{2}^{-}$removal efficiency with a $5 \mathrm{~min}$ EBCT (C1) than with a 10 min EBCT (C2). In fact, with a $5 \mathrm{~min}$ EBCT the $\mathrm{ClO}_{2}^{-}$concentration is always below $200 \mu \mathrm{g}$ $\mathrm{L}^{-1}$, while with a $10 \mathrm{~min} \mathrm{EBCT}$ it is higher, reaching values over the regulation limit of $700 \mu \mathrm{g} \mathrm{L}^{-1}$.

Overall, the virgin GACs, both mineral and vegetal, show a better performance with a $10 \mathrm{~min}$ EBCT, while the pre-loading behavior is not completely clear.

The $\mathrm{ClO}_{2}^{-}$concentrations after adsorption with the virgin mineral GAC in the small column tests at laboratory scale $(\mathrm{C} 1$ and $\mathrm{C} 2)$ and in the pilot column test at semi-full scale (P) are shown in Fig. 8. 


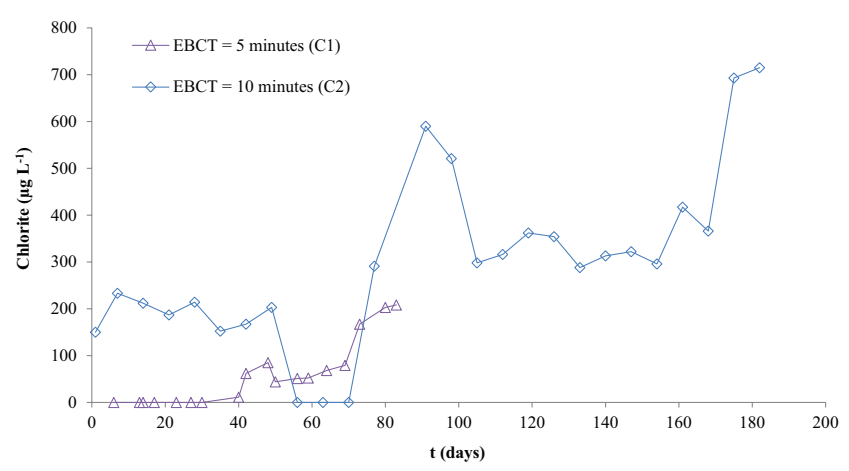

Fig. 7. Residual $\mathrm{ClO}_{2}^{-}$concentration in samples collected at the outlet of the pre-loaded mineral carbon columns operating with 5 and 10 min EBCT, respectively, in the first and second column tests (C1 and $\mathrm{C} 2)$.

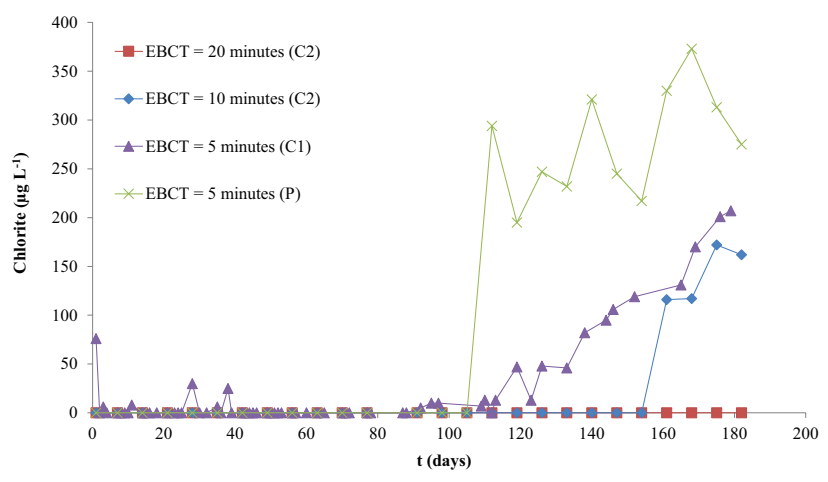

Fig. 8. Residual $\mathrm{ClO}_{2}^{-}$concentration in samples collected at the outlet of the virgin mineral GAC columns operating with 5, 10, and $20 \mathrm{~min}$ EBCT, in the first and second small column tests (C1 and $\mathrm{C} 2$ ) and in the pilot column test (P).

The results show that with increasing EBCT the $\mathrm{ClO}_{2}^{-}$ concentration at the outlet of the mineral GAC column decreases; moreover, with a 5-, 10-, and $20 \mathrm{~min}$ EBCT a 100\% $\mathrm{ClO}_{2}{ }^{-}$removal yield is obtained for about $3.5,5$, and 6 months, respectively. This confirms that a lower EBCT implies the carbon breakthrough achievement in a shorter period from the start-up of the column.

Comparing the pilot column $(\mathrm{P})$ with the $\mathrm{C} 1$ small column test, both operating with a $5 \mathrm{~min} \mathrm{EBCT}$, in the first case (P) the mineral GAC column allows a complete $\mathrm{ClO}_{2}{ }^{-}$removal till the 105th day of operation, and in the second case (C1) till the 92nd day. Therefore, the small column tests behavior is significantly representative of the pilot plant performance in terms of breakthrough. However, comparing the laboratory and pilot columns, the $\mathrm{ClO}_{2}^{-}$removal behavior changes after the breakthrough achievement. This could be due to chemical and physical factors, such as pore-surface diffusion and internal mass transfer, to the geometrical characteristics of the columns and the column wall effect that influence the hydrodynamic conditions [30].

Overall, as shown by the experimental results of this study, the performance of a full-scale GAC column can be realistically predicted by means of small column tests at laboratory scale and by means of column tests at pilot scale.

\section{Conclusions}

This paper shows how laboratory- and pilot-scale tests are useful to predict the GAC performance on the $\mathrm{ClO}_{2}^{-}$removal in a full-scale DWTP. Different experimental tests were carried out at laboratory scale by means of small columns and at pilot scale comparing a mineral and a vegetal GAC, in virgin and pre-loaded conditions. The results show that the virgin mineral carbon guarantees a higher $\mathrm{ClO}_{2}^{-}$removal efficiency than the vegetal one, while in pre-loaded conditions an opposite behavior is observed. Moreover, the carbon pre-loading significantly reduces the $\mathrm{ClO}_{2}^{-}$removal.

Small column tests and pilot column test show that a low EBCT implies the breakthrough achievement from the start-up of the GAC column in a short period.

Comparing the two types of tests, column experiments at laboratory scale are significantly representative of the pilot plant performance. Therefore, it can be stated that column tests at laboratory and pilot scale can predict the performance of a full-scale DWTP.

\section{Acknowledgments}

The authors would like to thank Centro Veneto Servizi (C.V.S.) SpA, which is the company that manages the Vescovana DWTP (Padova, Italy) studied in this research. Special thanks also go to Hydro-line technical staff that took part in this experimentation.

\section{References}

[1] P.C. Singer, Control of disinfection by-products in drinking water, J. Environ. Eng., 120 (1994) 727-744.

[2] C. Collivignarelli, S. Sorlini, Trihalomethane, chlorite and bromate formation in drinking water oxidation of Italian surface waters, J. Water Supply Res. Technol. AQUA, 53 (2004) 159-168.

[3] A.C. Diehl, G.E. Speitel, J.M. Symons, S.W. Krasner, C.J. Hwang, S.E. Barrett, DBP formation during chloramination, J. Am. Water Works Assoc., 92 (2000) 76-90.

[4] J. Choi, R.L. Valentine, Formation of $\mathrm{N}$-nitrosodimethylamine (NDMA) from reaction of monochloramine: a new disinfection by-product, Water Res., 36 (2002) 817-824.

[5] G. Hua, D.A. Reckhow, Factors Affecting the Formation of Disinfection Byproducts During Chlorination and Chloramination, Proceedings of the Water Quality Technology Conference, AWWA, Quebec City, Quebec, 2005.

[6] N. Mole, D. Lunt, M. Fielding, Influence of UV Disinfection on By-product Formation and the Operational Implications, Final Report, Drinking Water Inspectorate, London, 1997.

[7] Washington State Department of Health, Environmental Public Health Office of Drinking Water, Alternate Disinfectants Using Disinfectants Other than Chlorine, DOH 331-252, Washington, 2004.

[8] G. Hua, D.A. Reckhow, Comparison of disinfection byproduct formation from chlorine and alternative disinfectants, Water Res., 41 (2007) 1667-1678.

[9] S.D. Richardson, A.D. Thruston, T.V. Caughran, P.H. Chen, T.W. Collette, K.M. Schenck, V. Glezer, Identification of New Drinking Water Disinfection By-products from Ozone, Chlorine Dioxide, Chloramine, and Chlorine, Environmental Challenges, Springer Netherlands, 2000, 95-102.

[10] C. Korn, R.C. Andrews, M.D. Escobar, Development of chlorine dioxide-related by-product models for drinking water treatment, Water Res., 36 (2002) 330-342.

[11] W. Schmidt, Using chlorine dioxide for drinking water disinfection by the application of the chlorine/chlorite process, Acta Hydroch. Hydrob., 32 (2004) 48-60. 
[12] G.A. Gagnon, J.L. Rand, K.C. O'Leary, A.C. Rygel, C. Chauret, R.C. Andrews, Disinfectant efficacy of chlorite and chlorine dioxide in drinking water biofilms, Water Res., 39 (2005) 1809-1817.

[13] World Health Organization (WHO), Guidelines for Drinking Water Quality, 4th ed., WHO, Geneva, 2011.

[14] S. Sorlini, M. Biasibetti, F. Gialdini, M.C. Collivignarelli, How can drinking water treatments influence chlorine dioxide consumption and by-product formation in final disinfection?, Water Sci. Technol. Water Supply, 16 (2016) 333-346.

[15] Official Journal of Italy, Leg. Decree 31, Implementation of Directive 98/83/EC on Drinking Water Quality, 2001.

[16] Italian Decree 5, Modification of the Official Journal of Italy, Leg. Decree 31/2001, 2006.

[17] S. Sorlini, M. Biasibetti, M.C. Collivignarelli, B.M. Crotti, Reducing the chlorine dioxide demand in final disinfection of drinking water treatment plants using activated carbon, Environ. Technol., 36 (2015) 1499-1509.

[18] N. Gonce, E.A. Voudrias, Removal of chlorite and chlorate ions from water using granular activated carbon, Water Res., 28 (1994) 1059-1069.

[19] S. Sorlini, C.Collivignarelli, Chlorite removal with granular activated carbon, Desalination, 176 (2005) 255-265.

[20] C. Collivignarelli, S. Sorlini, M. Belluati, Chlorite removal with GAC, J. Am. Water Works Assoc., 98 (2006) 74-81.

[21] K.L. Dixon, R.G. Lee, Disinfection By-products Control: A Survey of American System Treatment Plants, AWWA Conference, Philadelphia, 1991.
[22] N.K. Vel Leitner, Use of $\mathrm{ClO}_{2}$ in Drinking Water Treatment: Formation and Control of Inorganic By-products $\left(\mathrm{ClO}_{2}^{-}, \mathrm{ClO}_{3}^{-}\right)$ R.A. Minear, G. Amy, Eds., Disinfection By-products in Water Treatment, CRC Press, Boca Raton, FL, 1996.

[23] S. Sorlini, M.C. Collivignarelli, M. Canato, Effectiveness in chlorite removal by two activated carbons under different working conditions: a laboratory study, J. Water Supply Res. Technol. AQUA, 64 (2015) 450-461.

[24] J.C. Crittenden, R.R. Trussel, D.W. Hand, K.J. Howe, G. Tchobanoglous, MWH's Water Treatment: Principles and Design, John Wiley \& Sons Inc., Manhattan, USA, 2005.

[25] J.C. Crittenden, P.S. Reddy, H. Arora, J. Trynoski, D.W. Hand, D.L. Perram, R.S. Summers, Predicting GAC performance with rapid small-scale column tests, J. Am. Water Works Assoc., 83 (1991) 77-87.

[26] Manuale 182 M, UNICHIM, Metodica M.35.

[27] Manuale 182 M, UNICHIM, Metodica M.36.

[28] Manuale 182 M, UNICHIM, Metodica M.37.

[29] UNI EN ISO 10304-4, Water Quality, Determination of Dissolved Anions by Ion Chromatography in Liquid Phase, Determination of Chlorates, Chlorides and Chlorites in Water with a Low Level of Contamination, 2001.

[30] J.C. Crittenden, J.K. Berrigan, D.W. Hand, Design of rapid fixedbed adsorption tests for non constant diffusivities, J. Environ. Eng., 113 (1987) 243-259. 